\title{
The Erythrocyte as Instigator of Inflammation Generation of Amidated C3 by Erythrocyte Adenosine Deaminase
}

\author{
Margaret K. Hostetter and George M. Johnson \\ With the technical assistance of Elena M. Retsinas \\ Department of Pediatrics, University of Minnesota Medical School, Minneapolis, Minnesota 55455
}

\begin{abstract}
Myocardial ischemia is characterized by the liberation of adenosine and by complement-mediated inflammation. We have reported that amidated $\mathbf{C} 3$, formed when ammonia $\left(\mathrm{NH}_{3}\right)$ disrupts the thiolester bond of $\mathrm{C} 3$, serves as an alternative pathway convertase, generates C5b-9, and stimulates phagocytic oxidative metabolism. We investigated whether the deamination of adenosine by adenosine deaminase in hematopoietic cells might liberate sufficient ammonia to form amidated C3 and thereby trigger complement-mediated inflammation at ischemic sites.

In the presence of $4 \mathrm{mM}$ adenosine, $\mathrm{NH}_{3}$ production per erythrocyte (RBC) was equal to that per neutrophil (PMN) $\left(3.3 \times 10^{-15} \mathrm{~mol} /\right.$ cell per h). Because RBC outnumber PMN in normal blood by a thousandfold, RBC are the major source of $\mathrm{NH}_{3}$ production in the presence of adenosine. $\mathrm{NH}_{3}$ production derived only from the deamination of adenosine by the enzyme adenosine deaminase and was abolished by $0.4 \mu \mathrm{M} 2$ '-deoxycoformycin, a specific inhibitor of adenosine deaminase.

When purified human C3 was incubated with $5 \times 10^{8}$ human $\mathrm{RBC}$ in the presence of adenosine, disruption of the $\mathrm{C} 3$ thiolester increased more than twofold over that measured in C3 incubated with buffer, or in C3 incubated with RBC (P $<0.05)$. The formation of amidated $\mathrm{C} 3$ was abolished by the preincubation of $\mathbf{R B C}$ with 2 -deoxycoformycin $(P<0.001)$. Amidated $\mathrm{C} 3$ elicited statistically significant release of superoxide, myeloperoxidase, and lactoferrin from PMN. Thus, the formation of amidated $\mathrm{C} 3$ by $\mathrm{RBC}$ deamination of adenosine triggers a cascade of complement-mediated inflammatory reactions.
\end{abstract}

\section{Introduction}

There is substantial evidence for the participation of complement proteins in ischemic myocardial injury. Nearly 20 years ago Hill and Ward demonstrated that a chemotactically active form of C3 was generated by the incubation of human or rat serum with a tissue homogenate from infarcted rat hearts.

Dr. Johnson's present address is Department of Pediatrics, University of Connecticut Health Center, 263 Farmington Avenue, Farmington, CT 06032.

Address reprint requests to Dr. M. K. Hostetter, UMHC Box 296, University of Minnesota, 420 Delaware St. SE, Minneapolis, MN 55455.

Received for publication 27 December 1988 and in revised form 7 March 1989.

J. Clin. Invest.

(c) The American Society for Clinical Investigation, Inc.

0021-9738/89/08/0665/07 \$2.00

Volume 84, August 1989, 665-671
Chemotactic activity was inhibited in vitro by incubation with an antibody to $\mathrm{C} 3$ and in vivo by depletion of rat $\mathrm{C} 3$ with cobra venom factor. The authors proposed that an enzyme in infarcted myocardium acted directly on C3 to generate inflammatory sequelae (1). Subsequent studies have provided ample confirmation of complement-dependent effects in experimental models of myocardial infarction in the rat, the dog, and the baboon, and have expanded the role of $\mathrm{C} 3$ to the mediation of physiologic, electrocardiographic, and histologic consequences of myocardial infarction (2-5).

However, the mechanism by which $\mathrm{C} 3$ mediates these sequelae has not been established. In addition to the direct activation mechanism suggested by Hill and Ward, subsequent studies have proposed the participation of the alternative complement pathway in an antibody-independent mechanism, while more recent investigations have focused on the role of subcellular components such as cardiolipin in antibody-independent activation of complement in normal hearts (6-9).

Because increases in local concentrations of adenosine also accompany myocardial ischemia (10), we propose that the increased concentrations of adenosine liberated at infarcted sites provide substrate for erythrocyte $(\mathrm{RBC})^{1}$ adenosine deaminase (ADA). In this paper we demonstrate how enzymatic deamination of adenosine releases $\mathrm{NH}_{3}$, which in turn leads to the formation of amidated $\mathrm{C} 3$, a biochemically reactive form of the third component of complement which has been shown to trigger complement-mediated inflammation.

Formed when free-base $\mathrm{NH}_{3}$ disrupts the internal thiolester bond of $\mathrm{C} 3$, amidated $\mathrm{C} 3$ engenders inflammatory sequelae by virtue of its "C3b-like" functions, including its ability to serve as an alternative pathway convertase, its amplification of C3 and C5 cleavage, its formation of the membrane attack complex, and its ability to bind to membrane complement receptors on phagocytic cells (11-13). In the kidney amidated C3 is formed by the reaction of plasma $\mathrm{C} 3$ with free-base $\mathrm{NH}_{3}$ in the peritubular capillaries $(12,13)$. In ischemic myocardium we propose that deamination of adenosine by RBC ADA provides a potent source of free-base $\mathrm{NH}_{3}$ for the amidation of $\mathrm{C} 3$. By this mechanism the RBC assumes an unexpected role in the initiation of inflammation at ischemic tissue sites.

\section{Methods}

$R B C$. Four adults (two males and two females) served as donors of RBC. All donors were in good health and taking no medications. Human RBC were separated from plasma and buffy coat by washing three times in $0.9 \%$ sodium chloride and were then resuspended to a concentration of $10 \%$ in a standard buffer consisting of $50 \mathrm{mM}$

1. Abbreviations used in this paper: ADA, adenosine deaminase; RBC, erythrocytes. 
$\mathrm{KH}_{2} \mathrm{PO}_{4}$, pH 7.5, $75 \mathrm{mM} \mathrm{NaCl}, 2 \mathrm{mM} \mathrm{MgSO}_{4}$, and $15 \mathrm{mM}$ Hepes (KPi/Hepes) according to published methods (14).

Adenosine (Calbiochem-Behring Corp., La Jolla, CA) was dissolved in $\mathrm{KPi} / \mathrm{Hepes}$ for a stock concentration of $16 \mathrm{mM}$. 2'-Deoxycoformycin (Pentostatin), a tight-binding inhibitor of ADA (14-17), was the gift of Martin L. Black of the Warner Lambert Co., Ann Arbor, MI. The compound was dissolved in water at $\mathrm{pH} 8.4$ and stored in a concentration of $0.5 \mathrm{mg} / \mathrm{ml}$ according to manufacturer's instructions.

$5 \times 10^{8}$ human $\mathrm{RBC}$ in $\mathrm{KPi} / \mathrm{Hepes}$ buffer were incubated in a $37^{\circ} \mathrm{C}$ water bath for varying time periods in the presence or absence of adenosine and purified human $\mathrm{C} 3(2 \mathrm{mg} / \mathrm{ml})$. After the appropriate incubation period the reaction mixtures were pelleted and the supernatants were withdrawn and aliquotted for measurement of $\mathrm{NH}_{3}$ concentration and analysis by affinity chromatography. In experiments assessing inhibition by $2^{\prime}$-deoxycoformycin, $\mathrm{RBC}$ were preincubated with $0.4 \mu \mathrm{M}$ deoxycoformycin in $\mathrm{KPi} / \mathrm{Hepes}$ buffer for $30 \mathrm{~min}$ at $37^{\circ} \mathrm{C}$ before the addition of $\mathrm{C} 3$ and/or adenosine.

$\mathrm{NH}_{3}$ assay. The $\mathrm{NH}_{3}$ assay used is a published method for the determination of total $\mathrm{NH}_{3}$ by the Bertholet reaction (18). Briefly, Dowex 50W-X4, 100-200 mesh (Sigma Chemical Co., St. Louis, MO) was washed as follows: one part of the resin was mixed with two parts of $2.5 \mathrm{M}$ sodium hydroxide and allowed to stand for $15 \mathrm{~min}$ with occasional mixing. After settling of the resin, the supernatant was decanted. The resin was then washed three to five times with distilled water, permitted to settle, and the water decanted. These washes were continued until the $\mathrm{pH}$ of the supernatant was neutral. One part resin was then mixed with two parts dilute acetic acid $(2 \mathrm{ml}$ glacial acetic acid/100 ml distilled water) and allowed to settle. After the acidic supernatant was decanted the resin was washed several times with distilled water and stored under water at room temperature.

Stock phenol reagent was made by dissolving $25 \mathrm{~g}$ of phenol and $130 \mathrm{mg}$ of sodium nitroprusside in $500 \mathrm{ml}$ of $\mathrm{NH}_{3}$-free distilled water. Phenol reagent was stored in a light-impermeable bottle at room temperature. Alkaline hypochlorite reagent was made by dissolving $6.25 \mathrm{~g}$ of sodium hydroxide in $200 \mathrm{ml}$ of $\mathrm{NH}_{3}$-free distilled water; after cooling of the mixture, $10 \mathrm{ml}$ of $5.25 \%$ sodium hypochlorite was added. Volume was brought to $250 \mathrm{ml}$ with $\mathrm{NH}_{3}$-free distilled water and the mixture was stored in a polyethylene bottle at room temperature.

The $\mathrm{NH}_{3}$ standard was made by dissolving $52.9 \mathrm{mg}$ of reagent grade ammonium sulfate $\left[\left(\mathrm{NH}_{4}\right)_{2} \mathrm{SO}_{4}\right]$ in a final vol of $125 \mathrm{ml}$ of $\mathrm{NH}_{3}$-free distilled water and was stored at $4^{\circ} \mathrm{C}$. For assay of $\mathrm{NH}_{3}$ production $0.500 \mathrm{ml}$ of washed resin was placed in $16 \times 100-\mathrm{mm}$ glass test tubes. The supernatant from the sample to be tested was pipetted directly onto the resin and gently mixed. $10 \mathrm{ml}$ of $\mathrm{NH}_{3}$-free distilled water was then added to each tube, the resin was allowed to settle, and the water was aspirated after settling. This step was repeated for a total of three washes, and after the third settling the water was aspirated just to the level of the resin. $1 \mathrm{ml}$ of the phenol stock was then added to each test tube, mixed, and allowed to stand for $3 \mathrm{~min}$ at room temperature. $1 \mathrm{ml}$ of the alkaline hypochlorite stock was then added to each test tube, mixed, and allowed to stand for $15 \mathrm{~min}$ at $37^{\circ} \mathrm{C}$ in a stationary water bath. $3 \mathrm{ml}$ of $\mathrm{NH}_{3}$-free distilled water was then added to each test tube, mixed, and the resin allowed to settle. Supernatant was withdrawn from the resin and the OD was measured at $630 \mathrm{~nm}$ on a UV/VIS spectrophotometer.

A standard curve consisting of concentrations of the $\mathrm{NH}_{3}$ standard ranging from 50 to $400 \mathrm{nmol} / \mathrm{ml}$ was performed with each day's samples, which were run in duplicate. As an internal control, a commercially available $\mathrm{NH}_{3}$ standard (Sigma Chemical Co.) was used to confirm the accuracy of the standard curve. Concentration of $\mathrm{NH}_{3}$ was calculated for each sample from the following formula: absorbance of sample/absorbance of standard $\times$ concentration of standard $=$ concentration of sample.

Isolation of C3. Human C3 was isolated from fresh plasma according to the methods of Tack et al. (19). Possible trace contaminants (IgG, IgA, and C5) were absorbed by affinity chromatography on cyanogen bromide-activated Sepharose 4B (Pharmacia Fine Chemicals, Piscataway, NJ) to which goat anti-human IgG, goat anti-human IgA, and goat anti-human $\mathrm{C} 5$ had been coupled according to manufacturer's instructions. C3 used in these experiments was therefore free of IgG, IgA, and C5 by SDS-PAGE, by double immunodiffusion against the above-named antibodies, and by affinity depletion of otherwise undetectable minor contaminants.

Affinity chromatography. Goat antiserum to human C3 (the kind gift of Dr. Brian F. Tack, Scripps Clinic, San Diego, CA), was treated with caprylic acid according to the procedure of Steinbuch and Audran (20). After removal of caprylic acid by dialysis at $4^{\circ} \mathrm{C}$ in PBS ( $\mathrm{pH} 7.4$ ), purity of the IgG fraction was checked on SDS-PAGE. The IgG fraction was then coupled to cyanogen bromide-activated Sepharose 4B according to manufacturer's instructions.

For affinity columns $0.5 \mathrm{ml}$ of affinity reagent was equilibrated with $50 \mathrm{mM} \mathrm{KH}_{2} \mathrm{PO}_{4}, \mathrm{pH} 7.5,2 \mathrm{mM} \mathrm{MgSO}_{4}$, and $75 \mathrm{mM} \mathrm{NaCl}$ $(\mathrm{KPi} / \mathrm{NaCl})$ in $1 \times 15-\mathrm{cm}$ disposable glass columns (Pierce Chemical Co., Rockford, IL). $244 \mu$ l of supernatant from reaction mixtures was applied to the affinity matrix, which was then washed with $10 \mathrm{ml}$ of $\mathrm{KPi} / \mathrm{NaCl}$. Neither protein nor tritium was ever detected in these eluates. $\mathrm{C} 3$ was eluted with $0.02 \mathrm{M} \mathrm{HCl}$ and $800-\mu$ l fractions were collected. After neutralization with $100 \mathrm{mM}$ Tris, $\mathrm{pH} 8.0$, and $10 \mathrm{mM}$ EDTA protein content was quantitated by measurement of absorbance at $280 \mathrm{~nm}$. Fractions containing protein were pooled and dialyzed repetitively in PBS to remove unbound radiolabel, and an aliquot was removed for measurement of thiolester disruption as described below. The remainder of each pool was then treated with reducing buffer, boiled, and stored at $-70^{\circ} \mathrm{C}$ before SDS-PAGE on $7.5 \%$ polyacrylamide gels according to the method of Laemmli (21).

Titration of thiolester disruption. Quantitation of thiolester disruption was performed by radioalkylation of the exposed sulfhydryl group, according to published procedures $(11,22,23)$. Briefly, reaction supernatants containing human $\mathrm{C} 3$ were incubated with $1.5 \mu \mathrm{l}$ of $\left[{ }^{3} \mathrm{H}\right]-$ iodoacetic acid (sp act, $10 \mathrm{mCi} / \mathrm{mM}$; Amersham Corp., Arlington Heights, IL) for $90 \mathrm{~min}$ in a $37^{\circ} \mathrm{C}$ water bath. Samples were then subjected to affinity chromatography for retrieval of human C3. After elution from the affinity matrix all samples containing $\mathrm{C} 3$ were pooled and dialyzed overnight against PBS to remove unbound $\left[{ }^{3} \mathrm{H}\right]$ iodoacetic acid. Concentration of $\mathrm{C} 3$ was determined by measurement of absorbance at $280 \mathrm{~nm}$; incorporation of [ ${ }^{3} \mathrm{H}$ ]iodoacetic acid was determined by counting $100 \mu \mathrm{l}$ of each sample in a scintillation counter (Beckman Instruments, Inc., Palo Alto, CA). Results are expressed as moles of $\left[{ }^{3} \mathrm{H}\right]$ iodoacetic acid/mole $\mathrm{C} 3$. Preparations of native $\mathrm{C} 3$ used in these experiments incorporated $0.06 \mathrm{~mol}\left[{ }^{3} \mathrm{H}\right]$ iodoacetic acid/mol $\mathrm{C} 3$; thus, minimal hydrolysis during purification resulted in disruption of the thiolester in $6 \%$ of $\mathrm{C} 3$ molecules.

Neutrophil studies. Neutrophils were isolated from the heparinized peripheral blood of healthy adult donors by dextran sedimentation, Ficoll (Pharmacia Fine Chemicals) separation in lymphocyte separation medium (Litton Bionetics, Inc., Kensington, MD), and hypotonic lysis of RBC. Purity and viability (the latter assessed by trypan blue exclusion) were $\geq 97 \%$ with these methods.

For experiments quantitating release of neutrophil products, amidated C3 was made by incubating purified human $\mathrm{C} 3(3.65 \mathrm{mg} / \mathrm{ml})$ with $1 \mathrm{M} \mathrm{NH}_{4} \mathrm{Cl}$ (final concentration, $0.1 \mathrm{M} \mathrm{NH}_{4} \mathrm{Cl}$ ) in $0.1 \mathrm{M}$ Tris, $0.01 \mathrm{M}$ EDTA, pH 8.0 , for $80 \mathrm{~min}$ in a $37^{\circ} \mathrm{C}$ water bath, according to our published methods (11-13). Amidated C3 was then dialyzed exhaustively in PBS to remove excess $\mathrm{NH}_{4} \mathrm{Cl}$, and thiolester disruption was quantitated by the method described above. All preparations of amidated $\mathrm{C} 3$ exhibited a disrupted thiolester in $>85 \%$ of the molecules. As described above, these preparations were absorbed with antiC5, anti-IgG, and anti-IgA Sepharose 4B before amidation to remove possible trace contaminants. For coupling to microspheres, amidated C3 $(0.4 \mathrm{mg} / \mathrm{ml})$ and gelatin $(0.5 \mathrm{mg} / \mathrm{ml})$ were dialyzed overnight in 0.1 $\mathrm{M} \mathrm{NaH}_{2} \mathrm{CO}_{3}, 0.5 \mathrm{M} \mathrm{NaCl}, \mathrm{pH} 8.5$, and then incubated with $1 \times 10^{10}$ $1-\mu \mathrm{m}$ MX-Covaspheres (Duke Scientific Corp., Palo Alto, CA) for 60 min at room temperature. Microspheres with deposited ligands were then washed three times with PBS/1\% gelatin and resuspended to $1 \mathrm{ml}$ in the same buffer, according to our published methods $(11,24)$. This procedure resulted in the deposition of $\sim 14,000$ molecules of ami- 
dated C3/microsphere. Microspheres coated with iC $3 b$ and $C 3 b$ were tested simultaneously. These results have been previously published (24).

The production of superoxide from $5 \times 10^{5}$ neutrophils was assessed by measuring the SDD-inhibitable reduction of cytochrome $c$ at $550 \mathrm{~nm}$ according to the microassay of Pick and Mizel (25). For superoxide assays, microspheres coated with amidated $\mathrm{C} 3$ or gelatin were used as the stimulus in a ratio of 1,000:1 (spheres/PMNs). For degranulation assays, PMNs were pretreated with cytochalasin B $(5 \mu \mathrm{g} / \mathrm{ml})$ and then stimulated with microspheres coated with amidated $\mathrm{C} 3$ in a ratio of 100:1 (spheres/PMNs). Myeloperoxidase was measured by the method of Webster and Henson (26), and lactoferrin was measured by the method of Hetherington et al. (27). The results of these assays are expressed as percent of total cellular myeloperoxidase or lactoferrin, determined after neutrophil lysis in $0.1 \%$ Triton X-100 in PBS, $0.5 \mathrm{M}$ $\mathrm{NaCl}$.

Statistics. Data were analyzed according to $t$ test; $P<0.05$ was considered significant.

\section{Results}

Fig. 1 (top) analyzes the production of $\mathrm{NH}_{3}$ by human $\mathrm{RBC}$ in response to increasing concentrations of adenosine. The $\mathrm{NH}_{3}$ produced by $5 \times 10^{6} \mathrm{PMN}$ was just $1 \%$ of that produced by 5 $\times 10^{8} \mathrm{RBC}$, shown on this graph. Although $\mathrm{NH}_{3}$ production did not differ between RBC and PMN on a cell-for-cell basis $\left(3.3 \times 10^{-15} \mathrm{~mol} / \mathrm{cell}\right.$ per $\mathrm{h}$ at an input of $4 \mathrm{mM}$ adenosine $)$,
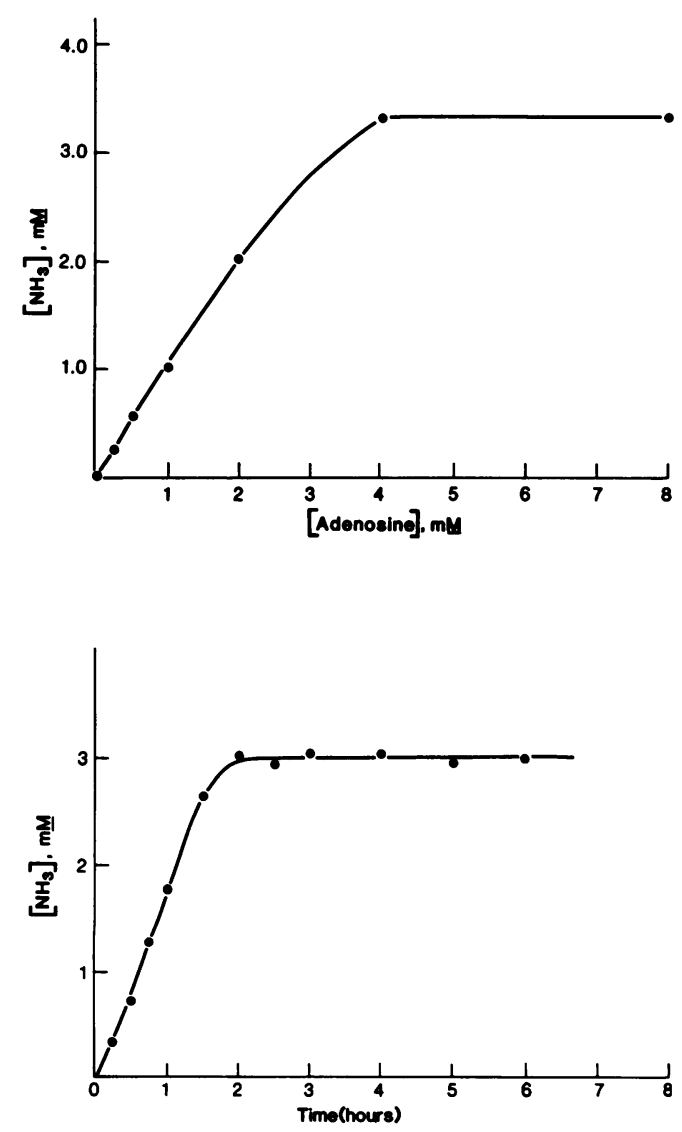

Figure 1. (Top) Dose-response curve for the production of $\mathrm{NH}_{3}$ by 5 $\times 10^{8}$ human $\mathrm{RBC}(10 \%$ of the normal hematocrit) in response to increasing concentrations of adenosine. (Bottom) Kinetics of $\mathrm{NH}_{3}$ production, which reaches a maximum at $2 \mathrm{~h}$ in the presence of 4 $\mathrm{mM}$ adenosine. the thousandfold preponderance of $\mathrm{RBC}$ in human blood makes them the major cellular source of $\mathrm{NH}_{3}$ in the bloodstream. As shown in the bottom graph, the time course of $\mathrm{NH}_{3}$ production reached a maximum between 1 and $2 \mathrm{~h}$ when $5 \times$ $10^{8} \mathrm{RBC}$ were incubated at $37^{\circ} \mathrm{C}$. Thus, for all subsequent experiments detailed in this paper, $4 \mathrm{mM}$ adenosine was incubated for $2 \mathrm{~h}$ at $37^{\circ} \mathrm{C}$ and physiologic $\mathrm{pH}$ with $5 \times 10^{8}$ human $\mathrm{RBC}, \sim 1 / 10$ the number of $\mathrm{RBC}$ in a milliliter of human blood.

Table I shows that production of $\mathrm{NH}_{3}$ by $\mathrm{RBC}$ occurred only in the presence of adenosine and was independent of the presence of $\mathrm{C} 3$. $\mathrm{NH}_{3}$ production was not detected in the supernatants from control mixtures of $5 \times 10^{8}$ human $\mathrm{RBC}$ and $\mathrm{C} 3$, or in the presence $4 \mathrm{mM}$ adenosine without $\mathrm{RBC}$. When the glucose concentration in the buffer system was varied between 5 and $50 \mathrm{mM}$, when the $\mathrm{pH}$ of the buffer was varied between 7.0 and 8.0 , or when the mixtures were bubbled with nitrogen to replace oxygen, $\mathrm{NH}_{3}$ production was not affected (data not shown). These observations are consistent with previous demonstrations that the activity of the enzyme ADA is stable to $\mathrm{pH}$ and ionic strength (28).

Fig. 2 shows that $\mathrm{NH}_{3}$ production by $5 \times 10^{8}$ human $\mathrm{RBC}$ was inhibited by increasing concentrations of $2^{\prime}$-deoxycoformycin. Maximal inhibition occurred at a concentration of 0.4 $\mu \mathrm{M}$ deoxycoformycin, which accords with previous publications $(14,16)$. These results confirm that $\mathrm{NH}_{3}$ measured in Fig. 1 and Table I is produced by the ADA-mediated deamination of adenosine.

The production of $\mathrm{NH}_{3}$ after deamination of adenosine by normal human RBC was sufficient for the formation of amidated C3 (Fig. 3). When purified human C3 (2.05 $\mathrm{mg} / \mathrm{ml})$ was incubated with $5 \times 10^{8}$ human $\mathrm{RBC}$ in the presence of $4 \mathrm{mM}$ adenosine, disruption of the $\mathrm{C} 3$ thiolester site, as measured by radioalkylation of the exposed sulfhydryl group, increased more than twofold over that measured in $\mathrm{C} 3$ alone, in $\mathrm{C} 3$ with $\mathrm{RBC}$, or in $\mathrm{C} 3$ with adenosine $(P<0.05)$. Thus, only the reaction that produced $\mathrm{NH}_{3}$ resulted in statistically significant disruption of the $\mathrm{C} 3$ thiolester.

As shown in Fig. 4, the generation of amidated C3 was abolished when $\mathrm{NH}_{3}$ production was inhibited by the preincubation of RBC with $0.4 \mu \mathrm{M}$ deoxycoformycin $(P<0.001)$. Thus, $\mathrm{NH}_{3}$ produced by the incubation of $\mathrm{RBC}$ with adenosine was sufficient to disrupt the thiolester bond in $\sim 15 \%$ of C3 molecules, whereas the preincubation of $\mathrm{RBC}$ with deoxycoformycin and the subsequent inhibition of ADA reduced disruption of the $\mathrm{C} 3$ thiolester by $60 \%$. Only $6 \%$ of $\mathrm{C} 3$ molecules exhibited a titrable sulfhydryl group after deoxycofor-

Table I. Production of Ammonia by RBC

\begin{tabular}{lc}
\hline \multicolumn{1}{c}{ Reaction mixture } & {$\left[\mathrm{NH}_{3}\right]^{*}$} \\
\hline & $m M$ \\
$4 \mathrm{mM}$ adenosine & 0.000 \\
$\mathrm{RBC}+$ buffer & $0.024 \pm 0.002$ \\
$\mathrm{RBC}+\mathrm{C} 3$ & $0.032 \pm 0.002$ \\
$\mathrm{RBC}+4 \mathrm{mM}$ adenosine & $2.78 \pm 0.28$ \\
$\mathrm{RBC}+4 \mathrm{mM}$ adenosine $+\mathrm{C} 3$ & $2.88 \pm 0.31$
\end{tabular}

* Data represent the mean \pm SEM for $n=5$ experiments. 


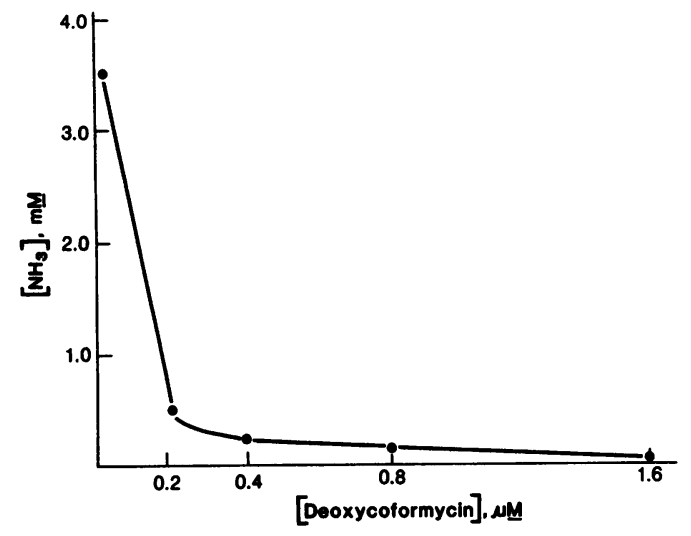

Figure 2. Inhibition of $\mathrm{NH}_{3}$ production after a 30-min preincubation of $5 \times 10^{8}$ human $\mathrm{RBC}$ with increasing concentrations of 2'-deoxycoformycin, a specific inhibitor of ADA.

mycin treatment of RBC; this figure did not differ significantly from thiolester disruption in purified human $\mathrm{C} 3$ alone (native C3) or in C3 incubated with adenosine and deoxycoformycin in the absence of $\operatorname{RBC}(P=0.2)$.

Fig. 5 displays the chain structures of the $\mathrm{C} 3$ molecules eluted after affinity chromatography on anti-C3 Sepharose 4B. The uncleaved $\alpha$ and $\beta$ chain structures of native C3 (lane 1 ) are present in all experimental supernatants (lanes 3-7), save for the control supernatant in lane 8 (RBC plus adenosine without $\mathrm{C} 3$ ), which contains neither $\mathrm{C} 3$ nor other visible proteins such as hemoglobin. Since all forms of nucleophile-modified C3 maintain the two-chain structure of the native protein, with an $\alpha$-chain of $115 \mathrm{kD}$ and a $\beta$-chain of $75 \mathrm{kD}(11,22-23)$, this gel confirms that the increase in thiolester disruption observed after ammoniagenesis (Fig. 3) is not attributable to proteolytic degradation of C3.

The reaction of amidated C3 with PMN led to the release of superoxide, myeloperoxidase, and lactoferrin, as shown in Fig. 6. Although amidated $\mathrm{C} 3$ is not so potent in this regard as phorbol myristate acetate, its effects equal or surpass those reported for other C3 ligands when bound to prototypic surfaces (24).

\section{Discussion}

The participation of the complement proteins in postischemic myocardial necrosis has been well established over nearly two

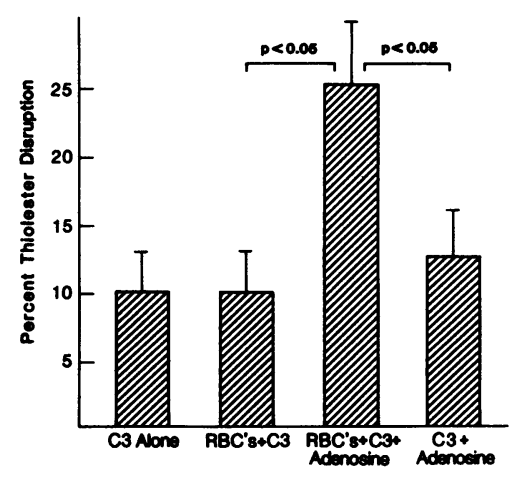

Figure 3. Formation of amidated $\mathrm{C} 3$ by the reaction of $\mathrm{NH}_{3}$ and purified human C3. Graph displays the mean \pm SEM percent thiolester disruption occurring in the various reaction mixtures. A significant increase in thiolester disruption occurred only with the liberation of $\mathrm{NH}_{3}(\mathrm{RBC}$

$+\mathrm{C} 3+4 \mathrm{mM}$ adenosine). $P<0.05$ for $n=$ 5 experiments.

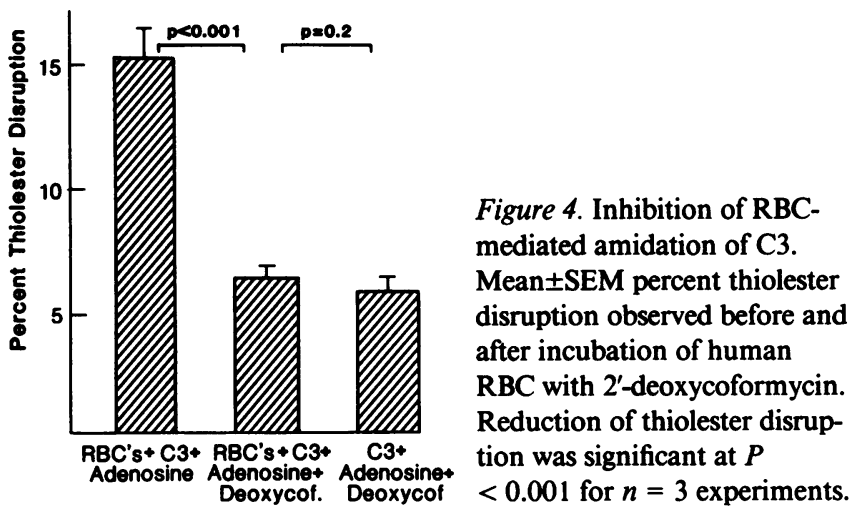

decades of investigation. After Hill and Ward's original demonstration that chemotactic activity and neutrophilic infiltration could be ablated by pharmacologic depletion of $\mathrm{C} 3$ with cobra venom factor in a rat model of myocardial infarction, other investigators used similar means to limit the degree of tissue damage after coronary artery occlusion, as assessed both by histology of epicardial biopsies and by the ratio of creatine kinase to ST segment elevation in canine models (1-3).

The clinical importance of these observations was emphasized by the demonstration of significant decreases in serum levels of several complement proteins $(\mathrm{Cl}, \mathrm{C} 4, \mathrm{C} 2$, and $\mathrm{C} 3)$ in patients during the first $72 \mathrm{~h}$ after myocardial infarction (6) and was confirmed in a model of infarction in nonhuman primates, where deposition of $\mathrm{C} 3$ was localized to sarcolemmal membranes of infarcted baboon heart but was absent in animals depleted of $\mathrm{C} 3$ with cobra venom factor before occlusion (5). Although experimental formulations of subcellular membrane constituents, such as cardiolipin vesicles, are now known to activate complement independently of antibody in studies with normal cardiac tissue (7-9), the factors responsible for complement-mediated inflammation after ischemia have remained unidentified. In this study we propose that the deamination of adenosine, found in increased concentrations at ischemic tissue sites, liberates sufficient $\mathrm{NH}_{3}$ to generate the potently active mediator, amidated $\mathrm{C} 3$.

The formation of amidated $\mathrm{C} 3$ by physiologic nucleophiles is a predictable consequence of the biochemistry of $\mathrm{C} 3$ and its internal thiolester bond and has been thoroughly elucidated $(22,23,29,30)$. Within the $\alpha$-chain of C3 there is a conserved sequence of seven amino acids (Gly-Cys-Gly-Glu-Glu-AsnMet) within which is contained the reactive thiolester bond which joins the cysteinyl residue to the second glutamyl residue. Nucleophilic amines such as $\mathbf{N H}_{3}$ or methylamine attack the thiolester directly, breaking the bond and forming an amide linkage at the glutamyl carbonyl. This reaction is stoichiometric and specific only for the second glutamyl carbonyl; amidated thiolester peptides have been sequenced for confirmation $(23,29)$.

Modification of $\mathrm{C} 3$ by nucleophiles such as methylamine or free-base $\mathrm{NH}_{3}$ endows the modified protein with $\mathrm{C} 3 \mathrm{~b}$-like properties (11-13, 31-33). Because of its structural similarities with $\mathrm{C} 3 \mathrm{~b}, \mathrm{NH}_{3}$-modified $\mathrm{C} 3$ (amidated $\mathrm{C} 3$ ) likewise forms the convertase for the alternative pathway and potentiates the amplification loop. By serving as an alternative pathway convertase amidated $\mathrm{C} 3$ cleaves $\mathrm{C} 5$ and promotes both the assembly of the membrane attack complex (C5b-9) and the libera- 


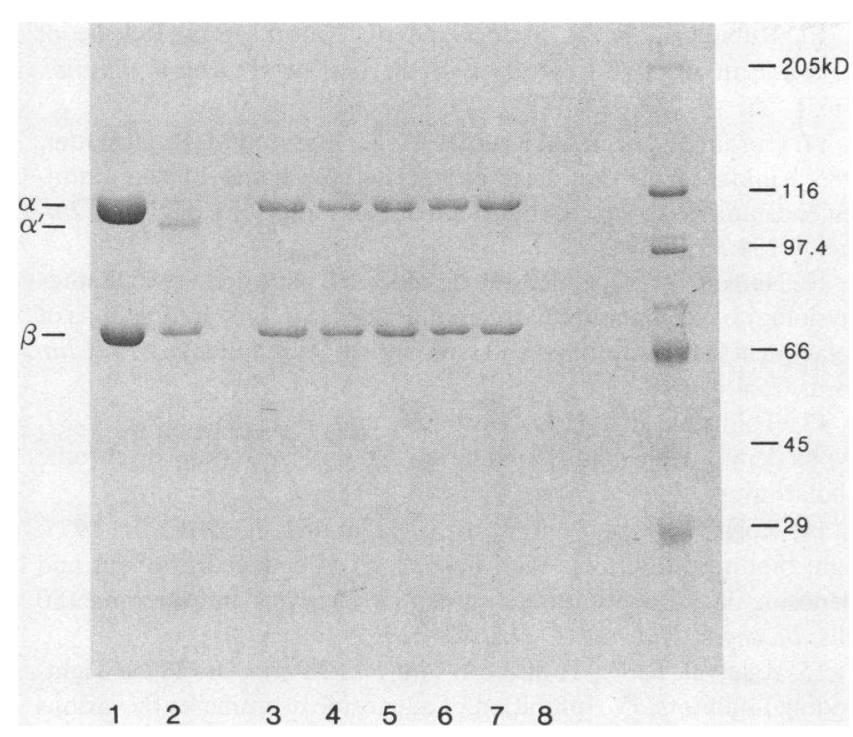

Figure 5. 7.5\% SDS-PAGE gel displaying eluates released after affinity chromatography on anti-C3 Sepharose 4B. Lane 1, native C3; lane 2, preformed $\mathrm{C} 3 \mathrm{~b}$; lane 3, supernatant from $\mathrm{C} 3$ incubated alone; lane 4, supernatant from $C 3+R B C$; lane 5, supernatant from $C 3$ $+\mathrm{RBC}+4 \mathrm{mM}$ adenosine; lane 6 , supernatant from $\mathrm{C} 3+4 \mathrm{mM}$ adenosine; lane 7, supernatant from $\mathrm{C} 3+\mathrm{RBC}+4 \mathrm{mM}$ adenosine +0.4 micromolar 2'-deoxycoformycin; lane 8 , supernatant from the incubation of $\mathrm{RBC}+$ adenosine without $\mathrm{C} 3$. No cleavage of $\mathrm{C} 3$ was observed in any reaction mixture.

tion of the chemotaxin C5a $(12,13)$. Finally, amidated C3 binds to membrane complement receptors on PMN and monocytes and triggers a chemiluminescent response (11). A review of the biochemical and biologic properties of amidated C3 has recently been published (34).

As we have shown in these studies, the binding of amidated C3 to neutrophil membranes is a potent stimulus for the release of superoxide, myeloperoxidase, and lactoferrin as well. Indeed, with amidated C 3 as the ligand on a prototypic surface, the amounts of inflammatory mediators released from the neutrophil equal, and in some cases surpass, the effects of other complement ligands such as $\mathrm{C} 3 \mathrm{~b}$ or $\mathrm{iC} 3 \mathrm{~b}$ (24). By triggering both the alternative pathway and the release of destructive products from activated neutrophil, amidated $\mathrm{C} 3$ thus sets in motion a cascade of potent inflammatory consequences.

In two experimental models of chronic renal disease we have provided both immunochemical and direct quantitative evidence of the link between increased renal ammoniagenesis and complement activation by amidated C $3(12,13)$. Because of the well-established increase in liberation of adenosine by ischemic tissue, ammoniagenesis may also be promoted at ischemic sites as well $(10,35)$. For example, although the concentration of adenosine in normoxic plasma is $0.100 \mu \mathrm{M}$, Rubio and colleagues measured a minimum concentration of $0.750 \mu \mathrm{M}$ in extracellular water after $30-60$-s occlusions of the left coronary artery in dogs (10). However, both the avid uptake of adenosine by RBC and its subsequent deamination within the cell can be expected to lower extracellular adenosine levels. Since $>95 \%$ of available adenosine is readily taken up by the cellular elements of blood (28), whole blood levels of adenosine plus its products, $\mathrm{NH}_{3}$ and hypoxanthine, probably exceed by several-fold the reported levels of adenosine in extracellular water.
On our dose-response curve (Fig. 1, top) we detected the liberation of substantial amounts of $\mathrm{NH}_{3}(250-530 \mu \mathrm{M})$ at adenosine concentrations of $250-500 \mu \mathrm{M}$. Moreover, in previous studies we have shown that $\mathrm{NH}_{3}$ concentrations of 250 $\mu \mathrm{M}$ are sufficient for the formation of amidated C3, the enzymatic activation of the alternative pathway, and the generation of C5b-9 $(12,13)$. Thus, concentrations of adenosine that correspond quite closely with those likely to be released at ischemic sites will provide sufficient $\mathrm{NH}_{3}$ for the generation of amidated $\mathrm{C} 3$ after deamination of adenosine by RBC ADA.

Other investigators have measured $\mathrm{NH}_{3}$ produced by the deamination of adenosine in human RBC (36). In one such study the rate of $\mathrm{NH}_{3}$ production was $0.2 \mathrm{mmol} / \mathrm{min}$ per $\mathrm{ml}$ packed RBC with $1 \mathrm{mM}$ adenosine as substrate. This activity corresponds quite closely to our measurement of $0.187 \mathrm{mmol}$ $\mathrm{NH}_{3} / \mathrm{min}$ per $\mathrm{ml}$ packed $\mathrm{RBC}$ in the presence of $1 \mathrm{mM}$ adenosine (Fig. 1). Neither human plasma nor platelets are effective sources of ADA, unlike other species (28). Thus, our observations on the avidity with which human RBC incorporate adenosine and on the rate of $\mathrm{NH}_{3}$ production after such incorporation are in agreement with previous reports.

Inhibitors of ADA have been extensively studied, both in human RBC and in malignant cell lines. For our studies we chose the tight-binding inhibitor 2'-deoxycoformycin, which is both more potent and more specific than the semi-tight binding inhibitor erythro-9-(2-hydroxyl-3-nonyl adenine) (15-18). Under standard assay conditions we were readily able to show that specific inhibition of RBC ADA by $2^{\prime}$-deoxycoformycin
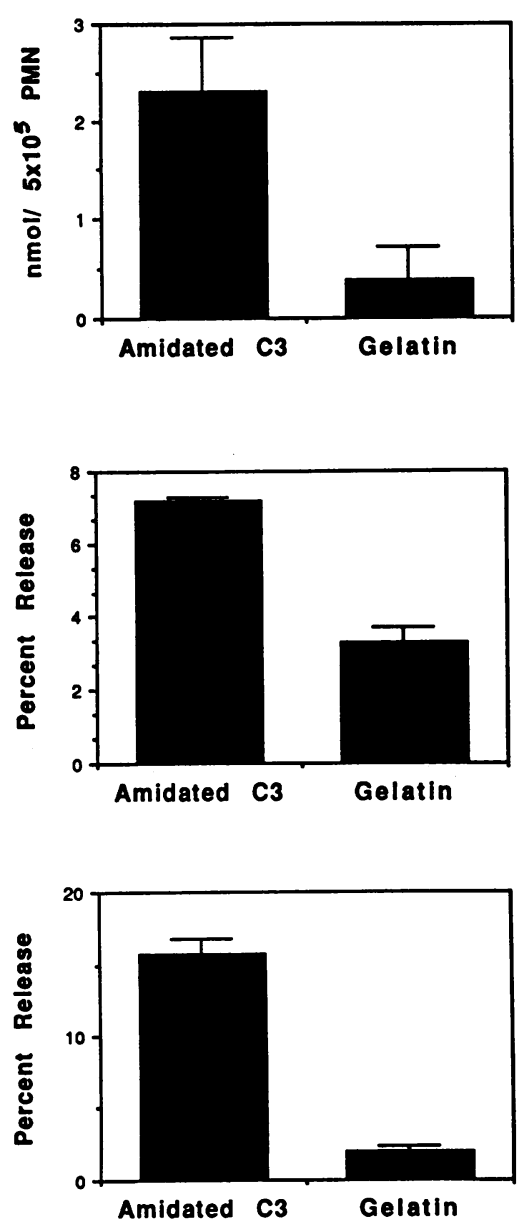

Figure 6. Release of superoxide (top), myeloperoxidase (center), and lactoferrin (bottom) from $5 \times 10^{5}$ human $\mathrm{PMN}$ in response to amidated $\mathrm{C} 3$ vs. gelatin. Comparisons were significant at $P<0.05$ for superoxide $(n=3)$ and $P<0.001$ for myeloperoxidase $(n=6)$ and lactoferrin $(n=4)$. 
inhibited both the production of $\mathrm{NH}_{3}$ and the formation of amidated C3 (Figs. 2 and 4). Although presently under study as a chemotherapeutic agent in hematogenous malignancies $(14,37,38), 2^{\prime}$-deoxycoformycin may have additional applications. Our results suggest that 2 '-deoxycoformycin may modulate complement-mediated necrosis at sites of adenosine release; study of the effects of deoxycoformycin in animal models of myocardial infarction is surely warranted.

These experiments provide a biochemical mechanism for the mediation of complement-dependent injury at sites of increased adenosine concentration. Liberation of $\mathrm{NH}_{3}$ by $\mathrm{RBC}$ ADA, even at $10 \%$ of the normal hematocrit, is sufficient for nucleophilic disruption of the $\mathrm{C} 3$ thiolester bond. As previously shown, the formation of amidated C3 leads to enzymatic activation of the alternative complement pathway, to the production of $\mathrm{C} 5 \mathrm{a}$ and $\mathrm{C} 5 \mathrm{~b}-9$, and to the initiation of phagocytic oxidative metabolism and neutrophil degranulation. Such a milieu could readily support neutrophil activation and the generation of oxygen-free radicals, which have been recently implicated in postischemic myocardial necrosis and reperfusion injury $(39,40)$. Inhibition of ADA by 2 -deoxycoformycin may constitute a novel strategy for controlling C3dependent sequelae at ischemic sites.

\section{Acknowledgments}

We are grateful to Dr. Thomas $\mathrm{H}$. Hostetter for many stimulating discussions. We thank Doreen Bower for expert secretarial assistance.

This study was supported by grants AI-07054 and 24162 from the National Institutes of Health.

\section{References}

1. Hill, J. H., and P. A. Ward. 1971. The phlogistic role of C3 leukotactic fragments in myocardial infarcts of rats. J. Exp. Med. 133:885-900.

2. Hartmann, J. R., J. A. Robinson, and R. M. Gunnar. 1977. Chemotactic activity in the coronary sinus after experimental myocardial infarction: effects of pharmacologic interventions on ischemic injury. Am. J. Cardiol. 40:550-555.

3. Maroko, P. R., C. B. Carpenter, M. Chiariello, M. C. Fishbein, P. Radvany, J. D. Knostman, and S. L. Hale. 1978. Reduction by cobra venom factor of myocardial necrosis after coronary artery occlusion. $J$. Clin. Invest. 61:661-670.

4. Maclean, D., M. C. Fishbein, E. Braunwald, and P. R. Maroko. 1978. Long-term preservation of ischemic myocardium after experimental coronary artery occlusion. J. Clin. Invest. 61:541-551.

5. Pinckard, R. N., R. A. O'Rourke, M. H. Crawford, F. S. Grover, L. M. McManus, J. J. Ghidoni, S. B. Storrs, and M. S. Olson. 1980. Complement localization and mediation of ischemic injury in baboon myocardium. J. Clin. Invest. 66:1050-1056.

6. Pinckard, R. N., M. S. Olson, P. C. Giclas, R. Terry, J. T. Boyer, and R. A. O'Rourke. 1975. Consumption of classical complement components by heart subcellular membranes in vitro and in patients after acute myocardial infarction. J. Clin. Invest. 56:740-750.

7. Giclas, P. C., R. N. Pinckard, and M. S. Olson. 1979. In vitro activation of complement by isolated human heart subcellular membranes. J. Immunol. 122:146-151.

8. Kovacsovics, T., J. Tschopp, A. Kress, and H. Isliker. 1985. Antibody-independent activation of $\mathrm{Cl}$, the first component of complement, by cardiolipin. J. Immunol. 135:2695-2700.

9. Peitsch, M. C., T. J. Kovacsovics, J. Tschopp, and H. Isliker. 1987. Antibody-independent activation of C1. J. Immunol. 138:1871-1876.
10. Rubio, R., R. M. Berne, and M. Katori. 1969. Release of adenosine in reactive hyperemia of the dog heart. Am. J. Physiol. 216:56-62.

11. Gordon, D. L., R. A. Krueger, P. G. Quie, and M. K. Hostetter. 1985. Amidation of $\mathrm{C} 3$ at the thiolester site: stimulation of chemiluminescence and phagocytosis by a new inflammatory mediator. J. Immunol. 134:3339-3345.

12. Nath, K. A., M. K. Hostetter, and T. H. Hostetter. 1985. Pathophysiology of chronic tubulo-interstitial disease in rats. Interactions of dietary acid load, ammonia, and complement component C3. J. Clin. Invest. 76:667-675.

13. Tolins, J. P., M. K. Hostetter, and T. H. Hostetter. 1987. Hypokalemic nephropathy in the rat. Role of ammonia in chronic tubular injury. J. Clin. Invest. 79:1447-1458.

14. Rogler-Brown, T., R. P. Agarwal, and R. E. Parks, Jr. 1977. Tight-binding inhibitors. VI. Interactions of deoxycoformycin and adenosine deaminase in intact human erythrocytes and sarcoma 180 cells. Biochem. Pharmacol. 27:2289-2296.

15. Agarwal, R. P., T. Spector, and R. E. Parks, Jr. 1977. Tightbinding inhibitors. IV. Inhibition of adenosine deaminases by various inhibitors. Biochem. Pharmacol. 26:359-367.

16. Henderson, J. F., L. Brox, G. Zombor, D. Hunting, and C. A. Lomax. 1977. Specificity of adenosine deaminase inhibitors. Biochem. Pharmacol. 26:1967-1972.

17. Agarwal, R. P. 1982. Inhibitors of adenosine deaminase. Pharmacol \& Ther. 17:399-429.

18. Bauer, J. D. 1982. Clinical Laboratory Methods. C. V. Mosby Co., St. Louis. 491.

19. Tack, B. F., J. Janatova, M. L. Thomas, R. A. Harrison, and C. H. Hammer. 1982. The third, fourth, and fifth components of complement: isolation and biochemical properties. Methods Enzymol. 80:64-101.

20. Steinbuch, M., and R. Audran. 1969. The isolation of IgG from mammalian sera with the aid of caprylic acid. Arch. Biochem. Biophys. 134:279-284.

21. Laemmli, U. K. 1970. Cleavage of structural proteins during the assembly of the head of bacteriophage T4. Nature (Lond.). 227:680-685.

22. Janatova, J., P. E. Lorenz, A. N. Schechter, J. W. Prahl, and B. F. Tack. 1980. Third component of human complement: appearance of a sulfhydryl group following chemical or enzymatic inactivation. Biochemistry. 19:4471-4478.

23. Tack, B. F., R. A. Harrison, J. Janatova, M. L. Thomas, and J. W. Prahl. 1980. Evidence for presence of an internal thiolester bond in third component of human complement. Proc. Natl. Acad. Sci. USA. 77:5764-5768.

24. Gordon, D. L., G. M. Johnson, and M. K. Hostetter. 1986. Ligand-receptor interactions in the phagocytosis of virulent Streptococcus pneumoniae by polymorphonuclear leukocytes. J. Infect. Dis. 154:619-626.

25. Pick, E., and D. Mizel. 1981. Rapid microassay for the measurement of superoxide and hydrogen peroxide production by macrophages in culture using an automatic enzyme immunoassay reader. $J$. Immunol. Methods. 46:211-226.

26. Webster, R. O., and P. M. Henson. 1978. Rapid micromeasurement of neutrophil exocytosis. Inflammation. 3:129-135.

27. Hetherington, S. V., J. K. Spitznagel, and P. G. Quie. 1983. An enzyme-linked immunoassay (ELISA) for measurement of lactoerrin. J. Immunol. Methods. 65:183-190.

28. van Belle, H. 1969. Uptake and deamination of adenosine by blood: species differences, effect of $\mathrm{pH}$, ions, temperature, and metabolic inhibitors. Biochim. Biophys. Acta. 192:124-132.

29. Hostetter, M. K., M. L. Thomas, F. S. Rosen, and B. F. Tack. 1982. Binding of $\mathrm{C} 3 \mathrm{~b}$ proceeds by a transesterification reaction at the thiolester site. Nature (Lond.). 298:372-375.

30. Hostetter, M. K., R. A. Krueger, and D. J. Schmeling. 1984. The biochemistry of opsonization: central role of the reactive thiolester of C3. J. Infect. Dis. 150:653-661. 
31. Isenman, D. E., D. I. Kells, N. R. Cooper, H. J. Muller-Eberhard, and M. K. Pangburn. 1981. Nucleophilic modification of human complement protein $\mathrm{C} 3$ : correlation of conformational changes with acquisition of C3b-like functional properties. Biochemistry. 20:44584467.

32. von Zabern, I., R. Nolte, and W. Vogt. 1981. Treatment of human complement components $\mathrm{C} 4$ and $\mathrm{C} 3$ with amines or chaotropic ions. Scand. J. Immunol. 13:413-431.

33. Schreiber, R. D., M. K. Pangburn, and H. J. Muller-Eberhard. 1981. C3 modified at the thiolester site: acquisition of reactivity with cellular C3b receptors. Biosci. Rep. 1:873-880.

34. Hostetter, M. K., and D. L. Gordon. 1987. Biochemistry of C3 and related thiolester proteins in infection and inflammation. Rev. Infect. Dis. 9:97-109.

35. Rubio, R., and R. M. Berne. 1969. Release of adenosine by the normal myocardium in dogs and its relationship to the regulation of coronary resistance. Circ. Res. 25:407-415.

36. Parks, R. E., G. W. Crabtree, C. M. Kong, R. P. Agarwal, K. C. Agarwal, and E. M. Scholar. 1975. Incorporation of analog purine nucleosides into the formed elements of human blood: erythrocytes, platelets, and lymphocytes. Ann. NY Acad. Sci. 255:412-434.

37. Agarwal, R. P. 1980. In vivo inhibition of adenosine deaminase by 2'-deoxycoformycin in mouse blood and leukemia L1210 cells. Biochem. Pharmacol. 29:187-193.

38. Spiers, A. S., D. Moore, P. A. Cassileth, D. P. Harrington, F. J. Cummings, R. S. Neiman, J. M. Bennett, and M. J. O’Connell. 1987. Remissions in hairy-cell leukemia with pentostatin (2'-deoxycoformycin). N. Engl. J. Med. 316:825-830.

39. Simpson, P. J., R. F. Todd III, J. C. Fantone, J. K. Kichelson, J. D. Griffin, and B. R. Lucchesi. 1988. Reduction of experimental canine myocardial reperfusion injury by a monoclonal antibody (antiMo1, anti-CD11b) that inhibits leukocyte adhesion. J. Clin. Invest. 81:624-629.

40. Bolli, R., B. S. Patel, M. O. Jeroudi, E. K. Lai, and P. B. McCay. 1988. Demonstration of free radical generation in "stunned" myocardium of intact dogs with the use of the spin trap a-phenyl $N$-tert-butyl nitrone. J. Clin. Invest. 82:476-485. 